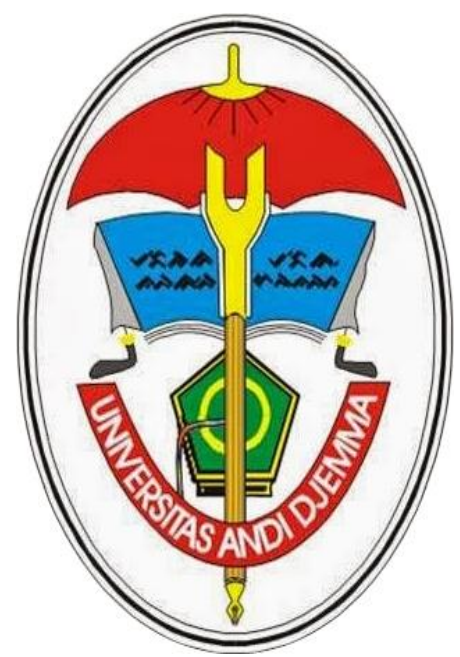

Oleh

Riski Sandy

NIM. 1802322201031

Dosen pembimbing:

AMIRUDDI AKBAR FISU, ST., MT.

FAKULTAS TEKNIK PRODI SIPIL

UNIVERSITAS ANDI DJEMMA

PALOPO2021 


\title{
ANALISIS PERTUMBUHAN PDRB DI KABUPATEN LUWU
}

\begin{abstract}
k
This paper analyzes and projects the growth of GRDP in Luwu Regency from various sectors using arithmetic and geometric methods. This paper is an assignment for a regional economics course.

\section{Abstrak}

Paper ini menganalisis dan memproyeksi pertumbuhan PDRB Kabupaten Luwu dari berbagai sektor menggunakan metode aritmatik dan geometrik. Paper ini merupakan tugas mata kuliah ekonomi wilayah.
\end{abstract}




\section{BAB I}

\subsection{Pendahuluan}

Ekonomi wilayah adalah ekonomi yang menekankan aspek ruang ke dalam analisis ekonomi .ilmu ekonomi tradisional dengan teori lokasi.

Ekonomi wilayah kota biasanya membahas tentang permasalahan ekonomi social suatu daerah secara keseluruhan salah satu contohnnya adalah membahas tentang produk domestik regional bruto(PDRB)

Produk Domestik Regional Bruto (PDRB) merupakan salah satu faktor penting untuk mengetahui kondisi ekonomi disuatu daerah dalam suatu periode tertentu, baik atas dasar harga berlaku maupun atas dasar harga konstan. Produk Domestik Regional Bruto (PDRB) atas harga berlaku menggambarkan nilai tambah barang dan jasa yang dihitung menggunakan harga per tahun berjalan, sedangkan Produk Domestik Regional Bruto (PDRB) atas dasar harga konstan menunjukkan nilai tambah barang dan jasa dihitung menggunakan harga yang berlaku pada satu tahun sebagai tahun dasar Pengertian domestik/regional disini dapat merupakan Propinsi atau Daerah Kabupaten/Kota. Transaksi Ekonomi yang akan dihitung adalah transaksi yang terjadi di wilayah domestik suatu daerah tanpa memperhatikan apakah transaksi dilakukan oleh masyarakat (residen) dari daerah tersebut atau masyarakat lain (non-residen).

PDRB meliputi:

- Upah dan gaji

- Bunga

- Sewa tanah

- Pajak tidak langsung

- Penyusutan

- Keuntungan

\section{2. landasan teori}

Sarana dan prasarana merupakan kebutuhan dasar dari suatu area permukiman (Fisu, 2018). Pemenuhan sarana dan prasarana tidak hanya untuk memenuhi kebutuhan permukiman, namun juga dapat meningkatkan perekonomian penduduk (Fisu, 2020) 


\section{BAB II \\ PEMBAHASAN}

Produk Domestik Regional Bruto (PDRB) merupakan salah satu faktor penting untuk mengetahui kondisi ekonomi disuatu daerah dalam suatu periode tertentu, baik atas dasar harga berlaku maupun atas dasar harga konstan. Produk Domestik Regional Bruto (PDRB) atas harga berlaku menggambarkan nilai tambah barang dan jasa yang dihitung menggunakan harga per tahun berjalan, sedangkan Produk Domestik Regional Bruto (PDRB) atas dasar harga konstan menunjukkan nilai tambah barang dan jasa dihitung menggunakan harga yang berlaku pada satu tahun sebagai tahun dasar, sebagai salah satu contohnya adalah kakao merupakan salah satu produk andalan kabupaten luwu dan merupakan komoditas penting dalam peningkatan ekonomi Nasional.

Adapun data PDRB Kabupaten Luwu lima tahun terakhir dan juga proyeksinya untuk lima tahun kedepan adalah sebagai berikut: 
Produk Domestik Regional Brut Atas Dasar Harga Berlaku Menurut Lapangan Usaha di Kabupaten Luwu ( miliar rupiah ), 2016-2020

\begin{tabular}{|c|c|c|c|c|c|c|}
\hline \multicolumn{2}{|r|}{ Lapangan Usaha /Industri } & 2016 & 2017 & 2018 & 2019 & 2020 \\
\hline \multicolumn{2}{|r|}{1} & 2 & 3 & 4 & 5 & 6 \\
\hline A & $\begin{array}{l}\text { Pertanian, Kehutanan, dan } \\
\text { Perikanan/Agriculture, Forestry, }\end{array}$ & 6435.09 & 6969.61 & 7781.89 & 8201.86 & 8353.52 \\
\hline B & $\begin{array}{l}\text { Pertambangan dan } \\
\text { Penggalian/Mining and Quarrying }\end{array}$ & 327.24 & 360.78 & 397.14 & 429.52 & 442.96 \\
\hline $\mathrm{C}$ & $\begin{array}{l}\text { Industri Pengolahan/ } \\
\text { Manufacturing }\end{array}$ & 476.38 & 541.3 & 595.41 & 668.83 & 638.79 \\
\hline $\mathrm{D}$ & $\begin{array}{l}\text { Pengadaan Listrik dan } \\
\text { Gas/Electricity and Gas }\end{array}$ & 7.84 & 10.5 & 11.52 & 12.1 & 12.56 \\
\hline $\mathrm{E}$ & $\begin{array}{l}\text { Pengadaan Air; Pengelolaan } \\
\text { Sampah, Limbah, dan Daur } \\
\text { Ulang/Water Supply; Sewerage, } \\
\text { Waste Management, and } \\
\text { Remediation Activities }\end{array}$ & 1.63 & 1.8 & 1.96 & 2.07 & 2.24 \\
\hline $\mathrm{F}$ & Konstruksi/Construction & 951.5 & 1064.96 & 1169.56 & 1349.18 & 1378.2 \\
\hline G & $\begin{array}{l}\text { Perdagangan Besar dan Eceran; } \\
\text { Reparasi Mobil dan Sepeda } \\
\text { Motor/Wholesale and Retail } \\
\text { Trade; Repair of Motor Vehicles } \\
\text { and Motorcycles }\end{array}$ & 1174.87 & 1273.94 & 1408.16 & 1587.98 & 1587.78 \\
\hline $\mathrm{H}$ & $\begin{array}{l}\text { Transportasi dan } \\
\text { Pergudangan/Transportation and } \\
\text { Storage }\end{array}$ & 97.56 & 103.92 & 121.37 & 135.69 & 124.04 \\
\hline I & $\begin{array}{l}\text { Penyediaan Akomodasi dan } \\
\text { Makan Minum/Accommodation } \\
\text { and Food Service Activities }\end{array}$ & 81.59 & 87.82 & 101.04 & 110.28 & 107.71 \\
\hline $\mathrm{J}$ & $\begin{array}{l}\text { Informasi dan Komunikasi/ } \\
\text { Information and Communication }\end{array}$ & 250.04 & 273.55 & 301.95 & 335.04 & 378.67 \\
\hline K & $\begin{array}{l}\text { Jasa Keuangan dan } \\
\text { Asuransi/Financial and Insurance } \\
\text { Activities }\end{array}$ & 169.8 & 187.17 & 204.94 & 218.61 & 230.74 \\
\hline $\mathrm{L}$ & Real Estat/Real Estate Activities & 682.49 & 759.59 & 821.14 & 881.8 & 936.34 \\
\hline $\mathrm{M}, \mathrm{N}$ & $\begin{array}{l}\text { Jasa Perusahaan/Business } \\
\text { Activities }\end{array}$ & 2.94 & 3.37 & 3.81 & 4,19 & 4.1 \\
\hline $\mathrm{O}$ & $\begin{array}{l}\text { Administrasi Pemerintahan, } \\
\text { Pertahanan, dan Jaminan Sosial } \\
\text { Wajib/Public Administration and } \\
\text { Defence; Compulsory Social } \\
\text { Security }\end{array}$ & 550.17 & 590.17 & 628.83 & 726.5 & 737.8 \\
\hline
\end{tabular}




\begin{tabular}{|c|l|r|r|r|r|r|}
\hline P & Jasa Pendidikan/Education & 400.13 & 435.43 & 492.52 & 545.34 & 587.38 \\
\hline Q & $\begin{array}{l}\text { Jasa Kesehatan dan Kegiatan } \\
\text { Sosia/Human Health and Social } \\
\text { Work Activities }\end{array}$ & 208.19 & 324.66 & 358.49 & 398.3 & 459.28 \\
\hline R,S,T,U & $\begin{array}{l}\text { Jasa Lainnya/Other Services } \\
\text { Activities }\end{array}$ & 34.38 & 38.25 & 45.2 & 50.38 & 48.96 \\
\hline & $\begin{array}{l}\text { Produk Domestik Regional } \\
\text { Bruto/Gross Regional Domestic } \\
\text { Product }\end{array}$ & 11851.86 & 13026.83 & 14441.94 & 15657.67 & 16031.07 \\
\hline
\end{tabular}




\section{Proyeksi Produk Domestik Regional Brut Atas Dasar Harga Berlaku Menurut Lapangan Usaha di Kabupaten Luwu ( miliar rupiah ), 5 Tahun kedepan}

- Pertanian, Kehutanan, dan Perikanan

\begin{tabular}{|c|c|c|c|c|c|}
\hline \multirow{2}{*}{ TAHUN } & \multirow{2}{*}{$\begin{array}{c}\text { Pertanian, Kehutanan, } \\
\text { dan Perikanan }\end{array}$} & \multicolumn{4}{|c|}{ PROYEKSINYA } \\
\cline { 3 - 6 } & & $\mathbf{r}$ & $\mathbf{P}$ & $\mathbf{r}$ & $\mathbf{P}$ \\
\cline { 3 - 4 } & & & 6435.09 & & 6435.09 \\
\hline 2016 & 6435.09 & & 6914.70 & & 6868.84 \\
\hline 2017 & 6969.61 & \multirow{2}{*}{$7.45 \%$} & 7394.31 & $6.74 \%$ & 7331.82 \\
\hline 2018 & 7781.89 & & 7873.91 & & 7826.02 \\
\hline 2019 & 8201.86 & & 8353.52 & & 8353.52 \\
\hline 2020 & 8353.52 & & 758.33 & & 758.57 \\
\hline \multicolumn{3}{|c|}{ Standar Deviasi } & 0.9748 & & 0.9667 \\
\hline 2025 & Koefisien Korelasi & 11466.46 & & 11574.79 \\
\hline \multicolumn{3}{|c|}{}
\end{tabular}

Syarat penentuan metode terbaik adalah:

-Standar Deviasi yang paling kecil

-Koefisien korelasi yang mendekati 1

Metode yang memenuhi syarat diatas adalah metode Aritmatika, jadi proyeksi PDRB bidang Pertanian, Kehutanan, dan Perikanan untuk Kabupaten Luwu 5 tahun kedepan adalah 11466.43 miliar rupiah.

- Pertambangan dan Penggalian

\begin{tabular}{|c|c|c|c|c|c|}
\hline \multirow{3}{*}{ TAHUN } & \multirow{3}{*}{$\begin{array}{c}\text { Pertambangan dan } \\
\text { Penggalian }\end{array}$} & \multicolumn{4}{|c|}{ PROYEKSINYA } \\
\hline & & \multicolumn{2}{|c|}{ ARITMATIKA } & \multicolumn{2}{|c|}{ GEOMETRIK } \\
\hline & & $r$ & $\mathbf{P}$ & $r$ & $\mathbf{P}$ \\
\hline 2016 & 327.24 & \multirow{5}{*}{$8.84 \%$} & 327.24 & \multirow{5}{*}{$7.86 \%$} & 327.24 \\
\hline 2017 & 360.78 & & 356.17 & & 352.97 \\
\hline 2018 & 397.14 & & 385.10 & & 380.73 \\
\hline 2019 & 429.52 & & 414.03 & & 410.67 \\
\hline 2020 & 442.96 & & 442.96 & & 442.96 \\
\hline \multicolumn{3}{|c|}{ Standar Deviasi } & 45.74 & & 45.76 \\
\hline \multicolumn{3}{|c|}{ Koefisien Korelasi } & 0.9897 & & 0.9832 \\
\hline 2025 & & & 638.76 & & 646.75 \\
\hline
\end{tabular}

Syarat penentuan metode terbaik adalah:

- Standar Deviasi yang paling kecil

- Koefisien korelasi yang mendekati 1 
Metode yang memenuhi syarat diatas adalah metode Aritmatika, jadi proyeksi PDRB bidang Petambangan dan Penggalian untuk Kabupaten Luwu 5 tahun kedepan adalah 638.76 miliar rupiah.

\section{- Industri Pengolahan}

\begin{tabular}{|c|c|c|c|c|c|}
\hline \multirow{2}{*}{ TAHUN } & \multirow{2}{*}{ Industri Pengolahan } & \multicolumn{4}{|c|}{ PROYEKSINYA } \\
\cline { 3 - 6 } & & \multicolumn{2}{|c|}{ ARITMATIKA } & \multicolumn{2}{c|}{ GEOMETRIK } \\
\cline { 3 - 6 } & & $\mathbf{r}$ & $\mathbf{P}$ & $\mathbf{r}$ & $\mathbf{P}$ \\
\hline 2016 & 476.38 & & 476.38 & & 476.38 \\
\hline 2017 & 541.30 & & 516.98 & \multirow{2}{*}{$7.61 \%$} & 551.64 \\
\hline 2018 & 595.41 & $8.52 \%$ & 557.59 & & 593.62 \\
\hline 2019 & 668.83 & & 598.19 & & 638.79 \\
\hline 2020 & 638.79 & 638.79 & & 64.22 \\
\hline \multicolumn{2}{|c|}{} & & 64.20 & & 0.9146 \\
\hline 2025 & Standar Deviasi & & 9.9285 & & 921.75 \\
\hline
\end{tabular}

Syarat penentuan metode terbaik adalah:

- Standar Deviasi yang paling kecil

- Koefisien korelasi yang mendekati 1

Metode yang memenuhi syarat diatas adalah metode Aritmatika, jadi proyeksi PDRB bidang Industri Pengolahan untuk Kabupaten Luwu 5 tahun kedepan adalah 911.01 miliar rupiah.

\section{- Pengadaan Listrik dan Gas}

\begin{tabular}{|c|c|c|c|c|c|}
\hline \multirow{3}{*}{ TAHUN } & \multirow{3}{*}{ Pengadaan Listrik dan Gas } & \multicolumn{4}{|c|}{ PROYEKSINYA } \\
\hline & & \multicolumn{2}{|c|}{ ARITMATIKA } & \multicolumn{2}{|c|}{ GEOMETRIK } \\
\hline & & $\mathbf{r}$ & $\mathbf{P}$ & $\mathbf{r}$ & $\mathbf{P}$ \\
\hline 2016 & 7.84 & \multirow{5}{*}{$15.05 \%$} & 7.84 & \multirow{5}{*}{$12.50 \%$} & 7.84 \\
\hline 2017 & 10.50 & & 9.02 & & 8.82 \\
\hline 2018 & 11.52 & & 10.20 & & 9.92 \\
\hline 2019 & 12.10 & & 11.38 & & 11.16 \\
\hline 2020 & 12.56 & & 12.56 & & 12.56 \\
\hline \multicolumn{3}{|c|}{ Standar Deviasi } & 1.87 & & 1.87 \\
\hline \multicolumn{3}{|c|}{ Koefisien Korelasi } & 0.9296 & & 0.9038 \\
\hline 2025 & & & 22.01 & & 22.64 \\
\hline
\end{tabular}

Syarat penentuan metode terbaik adalah:

- Standar Deviasi yang paling kecil

- Koefisien korelasi yang mendekati 1 
Metode yang memenuhi syarat diatas adalah metode Aritmatika, jadi proyeksi PDRB bidang Pengadaan Listrik dan Gas untuk Kabupaten Luwu 5 tahun kedepan adalah 22.01 miliar rupiah.

- Pengadaan Air; Pengelolaan Sampah, Limbah, dan Daur Ulang

\begin{tabular}{|c|c|c|c|c|c|}
\hline \multirow{3}{*}{ TAHUN } & \multirow{3}{*}{$\begin{array}{c}\text { Pengadaan Air; } \\
\text { Pengelolaan Sampah, } \\
\text { Limbah, dan Daur Ulang }\end{array}$} & \multicolumn{4}{|c|}{ PROYEKSINYA } \\
\hline & & \multicolumn{2}{|c|}{ ARITMATIKA } & \multicolumn{2}{|c|}{ GEOMETRIK } \\
\hline & & $\mathbf{r}$ & $\mathbf{P}$ & $r$ & $\mathbf{P}$ \\
\hline 2016 & 1.63 & \multirow{5}{*}{$9.36 \%$} & 1.63 & \multirow{5}{*}{$8.27 \%$} & 1.63 \\
\hline 2017 & 1.80 & & 1.78 & & 1.76 \\
\hline 2018 & 1.96 & & 1.94 & & 1.91 \\
\hline 2019 & 2.07 & & 2.09 & & 2.07 \\
\hline 2020 & 2.24 & & 2.24 & & 2.24 \\
\hline \multicolumn{3}{|c|}{ Standar Deviasi } & 0.24 & & 0.24 \\
\hline \multicolumn{3}{|c|}{ Koefisien Korelasi } & 0.9978 & & 0.9954 \\
\hline 2025 & & & 3.29 & & 3.33 \\
\hline
\end{tabular}

Syarat penentuan metode terbaik adalah:

- Standar Deviasi yang paling kecil

- Koefisien korelasi yang mendekati 1

Metode yang memenuhi syarat diatas adalah metode Aritmatika, jadi proyeksi PDRB bidang Pengadaan Air; Pengelolaan Sampah, Limbah, dan Daur Ulang untuk Kabupaten Luwu 5 tahun kedepan adalah 3.29 miliar rupiah.

\section{- Konstruksi}

\begin{tabular}{|c|c|c|c|c|c|}
\hline \multirow{2}{*}{ TAHUN } & \multirow{2}{*}{ Konstruksi } & \multicolumn{4}{|c|}{ PROYEKSINYA } \\
\cline { 3 - 5 } & & \multicolumn{2}{|c|}{ ARITMATIKA } & \multicolumn{2}{c|}{ GEOMETRIK } \\
\cline { 3 - 6 } & & $\mathbf{r}$ & $\mathbf{P}$ & $\mathbf{r}$ & $\mathbf{P}$ \\
\hline 2016 & 951.50 & & 951.50 & & 951.50 \\
\hline 2017 & 1064.96 & \multirow{2}{*}{$11.21 \%$} & 1164.85 & \multirow{2}{*}{$9.70 \%$} & 1145.15 \\
\hline 2018 & 1169.56 & & 1271.53 & & 1256.28 \\
\hline 2019 & 1349.18 & 1378.20 & & 1378.20 \\
\hline 2020 & 1378.20 & & 168.67 & & 168.78 \\
\hline \multicolumn{2}{|c|}{ Standar Deviasi } & & 2150.77 & & 0.9794 \\
\hline 2025 & Koefisien Korelasi & & & 2189.99 \\
\hline
\end{tabular}

Syarat penentuan metode terbaik adalah:

- Standar Deviasi yang paling kecil

- Koefisien korelasi yang mendekati 1 
Metode yang memenuhi syarat diatas adalah metode Aritmatika, jadi proyeksi PDRB bidang Konstruksi untuk Kabupaten Luwu 5 tahun kedepan adalah 2150.77 miliar rupiah.

- Perdagangan Besar dan Eceran; Reparasi Mobil dan Sepeda Motor

\begin{tabular}{|c|c|c|c|c|c|}
\hline \multirow{3}{*}{ TAHUN } & \multirow{3}{*}{$\begin{array}{l}\text { Perdagangan Besar dan } \\
\text { Eceran; Reparasi Mobil } \\
\text { dan Sepeda Motor }\end{array}$} & \multicolumn{4}{|c|}{ PROYEKSINYA } \\
\hline & & \multicolumn{2}{|c|}{ ARITMATIKA } & \multicolumn{2}{|c|}{ GEOMETRIK } \\
\hline & & $\mathbf{r}$ & $\mathbf{P}$ & $r$ & $\mathbf{P}$ \\
\hline 2016 & 1174.87 & \multirow{5}{*}{$8.79 \%$} & 1174.87 & \multirow{5}{*}{$7.82 \%$} & 1174.87 \\
\hline 2017 & 1155.96 & & 1278.10 & & 1266.75 \\
\hline 2018 & 1408.16 & & 1381.33 & & 1365.81 \\
\hline 2019 & 1587.98 & & 1484.55 & & 1472.62 \\
\hline 2020 & 1587.78 & & 1587.78 & & 1587.78 \\
\hline \multicolumn{3}{|c|}{ Standar Deviasi } & 163.22 & & 163.29 \\
\hline \multicolumn{3}{|c|}{ Koefisien Korelasi } & 0.9390 & & 0.9367 \\
\hline 2025 & & & 2285.31 & & 2313.61 \\
\hline
\end{tabular}

Syarat penentuan metode terbaik adalah:

- Standar Deviasi yang paling kecil

- Koefisien korelasi yang mendekati 1

Metode yang memenuhi syarat diatas adalah metode Aritmatika, jadi proyeksi PDRB bidang Perdagangan Besar dan Eceran; Reparasi Mobil dan Sepeda Motor untuk Kabupaten Luwu 5 tahun kedepan adalah 2285.31 miliar rupiah.

- Transportasi dan Pergudangan

\begin{tabular}{|c|c|c|c|c|c|}
\hline \multirow{3}{*}{ TAHUN } & \multirow{3}{*}{$\begin{array}{l}\text { Transportasi dan } \\
\text { Pergudangan }\end{array}$} & \multicolumn{4}{|c|}{ PROYEKSINYA } \\
\hline & & \multicolumn{2}{|c|}{ ARITMATIKA } & \multicolumn{2}{|c|}{ GEOMETRIK } \\
\hline & & $r$ & $\mathbf{P}$ & $r$ & $\mathbf{P}$ \\
\hline 2016 & 97.56 & \multirow{5}{*}{$6.79 \%$} & 97.56 & \multirow{5}{*}{$6.19 \%$} & 97.56 \\
\hline 2017 & 103.92 & & 104.18 & & 103.60 \\
\hline 2018 & 121.37 & & 110.80 & & 110.01 \\
\hline 2019 & 135.69 & & 117.42 & & 116.81 \\
\hline 2020 & 124.04 & & 124.04 & & 124.04 \\
\hline \multicolumn{3}{|c|}{ Standar Deviasi } & 10.47 & & 10.47 \\
\hline \multicolumn{3}{|c|}{ Koefisien Korelasi } & 0.8622 & & 0.8494 \\
\hline 2025 & & & 166.12 & & 167.47 \\
\hline
\end{tabular}

Syarat penentuan metode terbaik adalah:

- Standar Deviasi yang paling kecil

- Koefisien korelasi yang mendekati 1 
Metode yang memenuhi syarat diatas adalah metode Aritmatika, jadi proyeksi PDRB bidang Transportasi dan Pergudangan untuk Kabupaten Luwu 5 tahun kedepan adalah 166.12 miliar rupiah.

\section{- Penyediaan Akomodasi dan Makan Minum}

\begin{tabular}{|c|c|c|c|c|c|}
\hline \multirow{2}{*}{ TAHUN } & \multirow{2}{*}{$\begin{array}{c}\text { Penyediaan Akomodasi } \\
\text { dan Makan Minum }\end{array}$} & \multicolumn{4}{|c|}{ PROYEKSINYA } \\
\cline { 3 - 6 } & & $\mathbf{r}$ & $\mathbf{2}$ & $\mathbf{2}$ & $\mathbf{r}$ \\
\cline { 3 - 6 } & & & 81.59 & & 81.59 \\
\hline 2016 & 81.59 & & 88.12 & & 87.46 \\
\hline 2017 & 87.82 & \multirow{2}{*}{$8.00 \%$} & 94.65 & $7.19 \%$ & 93.74 \\
\hline 2018 & 101.04 & & 101.18 & & 100.49 \\
\hline 2019 & 110.28 & & 107.71 & & 107.71 \\
\hline 2020 & 107.71 & & 10.32 & & 10.33 \\
\hline \multicolumn{2}{r}{} \\
\cline { 3 - 5 } & Standar Deviasi & & 150.81 & & 0.9331 \\
\hline 2025 & Koefisien Korelasi & & & 152.42 \\
\hline
\end{tabular}

Syarat penentuan metode terbaik adalah:

- Standar Deviasi yang paling kecil

- Koefisien korelasi yang mendekati 1

Metode yang memenuhi syarat diatas adalah metode Aritmatika, jadi proyeksi PDRB bidang Penyediaan Akomodasi dan Makan Minum untuk Kabupaten Luwu 5 tahun kedepan adalah 150.81 miliar rupiah.

- Informasi dan Komunikasi

\begin{tabular}{|c|c|c|c|c|c|}
\hline \multirow{2}{*}{ TAHUN } & \multirow{2}{*}{ Informasi dan Komunikasi } & \multicolumn{4}{|c|}{ PROYEKSINYA } \\
\cline { 3 - 6 } & & $\mathbf{2}$ & $\mathbf{2}$ & \multicolumn{2}{c|}{ GEOMETRIK } \\
\cline { 3 - 6 } & & $\mathbf{r}$ & 250.04 & $\mathbf{r}$ & $\mathbf{P}$ \\
\hline 2016 & 250.04 & & 282.20 & & 277.38 \\
\hline 2017 & 273.55 & \multirow{2}{*}{$12.86 \%$} & 314.36 & \multirow{2}{*}{$10.93 \%$} & 307.71 \\
\hline 2018 & 301.95 & & 346.51 & & 341.35 \\
\hline 2019 & 335.04 & 378.67 & & 378.67 \\
\hline 2020 & 378.67 & 50.85 & & 50.89 \\
\hline \multicolumn{2}{|r|}{} & & 0.9928 & & 0.9982 \\
\hline 2025 & Standar Deviasi & 622.17 & & 636.17 \\
\hline
\end{tabular}

Syarat penentuan metode terbaik adalah:

- Standar Deviasi yang paling kecil

- Koefisien korelasi yang mendekati 1 
Metode yang memenuhi syarat diatas adalah metode Aritmatika, jadi proyeksi PDRB bidang Penyediaan Informasi dan Komunikasi untuk Kabupaten Luwu 5 tahun kedepan adalah 622.17 miliar rupiah.

\section{- Jasa Keuangan dan Asuransi}

\begin{tabular}{|c|c|c|c|c|c|}
\hline \multirow{3}{*}{ TAHUN } & \multirow{3}{*}{$\begin{array}{c}\text { Jasa Keuangan dan } \\
\text { Asuransi }\end{array}$} & \multicolumn{4}{|c|}{ PROYEKSINYA } \\
\hline & & \multicolumn{2}{|c|}{ ARITMATIKA } & \multicolumn{2}{|c|}{ GEOMETRIK } \\
\hline & & $r$ & $\mathbf{P}$ & $r$ & $\mathbf{P}$ \\
\hline 2016 & 169.80 & \multirow{5}{*}{$8.97 \%$} & 169.80 & \multirow{5}{*}{$7.97 \%$} & 169.80 \\
\hline 2017 & 187.17 & & 185.04 & & 183.33 \\
\hline 2018 & 204.94 & & 200.27 & & 197.94 \\
\hline 2019 & 218.61 & & 215.51 & & 213.71 \\
\hline 2020 & 230.74 & & 230.74 & & 230.74 \\
\hline \multicolumn{3}{|c|}{ Standar Deviasi } & 24.09 & & 24.10 \\
\hline \multicolumn{3}{|c|}{ Koefisien Korelasi } & 0.9966 & & 0.9919 \\
\hline 2025 & & & 334.25 & & 338.54 \\
\hline
\end{tabular}

Syarat penentuan metode terbaik adalah:

- Standar Deviasi yang paling kecil

- Koefisien korelasi yang mendekati 1

Metode yang memenuhi syarat diatas adalah metode Aritmatika, jadi proyeksi PDRB bidang Jasa Keuangan dan Asuransi untuk Kabupaten Luwu 5 tahun kedepan adalah 334.25miliar rupiah.

- Real Estat

\begin{tabular}{|c|c|c|c|c|c|}
\hline \multirow{3}{*}{ TAHUN } & \multirow{3}{*}{$\begin{array}{l}\text { Pertanian, Kehutanan, } \\
\text { dan Perikanan }\end{array}$} & \multicolumn{4}{|c|}{ PROYEKSINYA } \\
\hline & & \multicolumn{2}{|c|}{ ARITMATIKA } & \multicolumn{2}{|c|}{ GEOMETRIK } \\
\hline & & $r$ & $\mathbf{P}$ & $r$ & $\mathbf{P}$ \\
\hline 2016 & 682.49 & \multirow{5}{*}{$9.30 \%$} & 682.49 & \multirow{5}{*}{$8.23 \%$} & 682.49 \\
\hline 2017 & 759.59 & & 745.95 & & 738.64 \\
\hline 2018 & 821.14 & & 809.42 & & 799.40 \\
\hline 2019 & 881.80 & & 872.88 & & 865.17 \\
\hline 2020 & 936.34 & & 936.34 & & 936.34 \\
\hline \multicolumn{3}{|c|}{ Standar Deviasi } & 100.34 & & 100.39 \\
\hline \multicolumn{3}{|c|}{ Koefisien Korelasi } & 0.9979 & & 0.9940 \\
\hline 2025 & & & 1371.68 & & 1390.29 \\
\hline
\end{tabular}

Syarat penentuan metode terbaik adalah:

- Standar Deviasi yang paling kecil

- Koefisien korelasi yang mendekati 1 
Metode yang memenuhi syarat diatas adalah metode Aritmatika, jadi proyeksi PDRB bidang Real Estat untuk Kabupaten Luwu 5 tahun kedepan adalah 1371.68miliar rupiah.

\section{- Jasa Perusahaan}

\begin{tabular}{|c|c|c|c|c|c|}
\hline \multirow{3}{*}{ TAHUN } & \multirow{3}{*}{ Jasa Perusahaan } & \multicolumn{4}{|c|}{ PROYEKSINYA } \\
\hline & & \multicolumn{2}{|c|}{ ARITMATIKA } & \multicolumn{2}{|c|}{ GEOMETRIK } \\
\hline & & $r$ & $\mathbf{P}$ & $r$ & $\mathbf{P}$ \\
\hline 2016 & 2.94 & \multirow{5}{*}{$9.86 \%$} & 2.94 & \multirow{5}{*}{$8.67 \%$} & 2.94 \\
\hline 2017 & 3.37 & & 3.23 & & 3.19 \\
\hline 2018 & 3.81 & & 3.52 & & 3.47 \\
\hline 2019 & 4,19 & & 3.81 & & 3.77 \\
\hline 2020 & 4.10 & & 4.10 & & 4.10 \\
\hline \multicolumn{3}{|c|}{ Standar Deviasi } & 0.46 & & 0.46 \\
\hline \multicolumn{3}{|c|}{ Koefisien Korelasi } & 0.9623 & & 0.9481 \\
\hline 2025 & & & 6.12 & & 6.21 \\
\hline
\end{tabular}

Syarat penentuan metode terbaik adalah:

- Standar Deviasi yang paling kecil

- Koefisien korelasi yang mendekati 1

Metode yang memenuhi syarat diatas adalah metode Aritmatika, jadi proyeksi PDRB bidang Jasa Perusahaan untuk Kabupaten Luwu 5 tahun kedepan adalah 6.12 miliar rupiah.

- Administrasi Pemerintahan, Pertahanan, dan Jaminan Sosial Wajib

\begin{tabular}{|c|c|c|c|c|c|}
\hline \multirow{3}{*}{ TAHUN } & \multirow{3}{*}{$\begin{array}{c}\text { Administrasi } \\
\text { Pemerintahan, } \\
\text { Pertahanan, dan Jaminan } \\
\text { Sosial Wajib }\end{array}$} & \multicolumn{4}{|c|}{ PROYEKSINYA } \\
\hline & & \multicolumn{2}{|c|}{ ARITMATIKA } & \multicolumn{2}{|c|}{ GEOMETRIK } \\
\hline & & $r$ & $\mathbf{P}$ & $\mathbf{r}$ & $\mathbf{P}$ \\
\hline 2016 & 550.17 & \multirow{5}{*}{$8.53 \%$} & 550.17 & \multirow{5}{*}{$7.61 \%$} & 550.17 \\
\hline 2017 & 590.17 & & 597.08 & & 592.05 \\
\hline 2018 & 628.83 & & 643.99 & & 637.11 \\
\hline 2019 & 726.50 & & 690.89 & & 685.61 \\
\hline 2020 & 737.80 & & 737.80 & & 737.80 \\
\hline \multicolumn{3}{|c|}{ Standar Deviasi } & 74.17 & & 74.20 \\
\hline \multicolumn{3}{|c|}{ Koefisien Korelasi } & 0.9756 & & 0.9746 \\
\hline 2025 & & & 1052.32 & & 1064.73 \\
\hline
\end{tabular}

Syarat penentuan metode terbaik adalah:

- Standar Deviasi yang paling kecil

- Koefisien korelasi yang mendekati 1 
Metode yang memenuhi syarat diatas adalah metode Aritmatika, jadi proyeksi PDRB bidang Administrasi Pemerintahan, Pertahanan, dan Jaminan Sosial Wajib untuk Kabupaten Luwu 5 tahun kedepan adalah 1052.32 miliar rupiah

- Jasa Pendidikan

\begin{tabular}{|c|c|c|c|c|c|}
\hline \multirow{2}{*}{ TAHUN } & \multirow{2}{*}{ Jasa Pendidikan } & \multicolumn{4}{|c|}{ PROYEKSINYA } \\
\cline { 3 - 6 } & & \multicolumn{2}{|c|}{ ARITMATIKA } & \multicolumn{2}{c|}{ GEOMETRIK } \\
\cline { 3 - 6 } & & $\mathbf{r}$ & $\mathbf{P}$ & $\mathbf{r}$ & $\mathbf{P}$ \\
\hline 2016 & 400.13 & & 400.13 & & 400.13 \\
\hline 2017 & 435.43 & \multirow{2}{*}{$11.70 \%$} & 493.76 & \multirow{2}{*}{$10.07 \%$} & 484.80 \\
\hline 2018 & 492.52 & & 540.57 & & 533.63 \\
\hline 2019 & 545.34 & & 587.38 & & 587.38 \\
\hline 2020 & 587.38 & & 74.02 & & 74.07 \\
\hline \multicolumn{2}{|r|}{} & & 0.9975 & & 0.9967 \\
\hline 2025 & Standar Deviasi & 930.98 & & 949.11 \\
\hline
\end{tabular}

Syarat penentuan metode terbaik adalah:

- Standar Deviasi yang paling kecil

- Koefisien korelasi yang mendekati 1

Metode yang memenuhi syarat diatas adalah metode Aritmatika, jadi proyeksi PDRB bidang Jasa Pendidikan untuk Kabupaten Luwu tahun kedepan adalah 930.98 miliar rupiah.

- Jasa Kesehatan dan Kegiatan Sosial

\begin{tabular}{|c|c|c|c|c|c|}
\hline \multirow{3}{*}{ TAHUN } & \multirow{3}{*}{$\begin{array}{l}\text { Jasa Kesehatan dan } \\
\text { Kegiatan Sosial }\end{array}$} & \multicolumn{4}{|c|}{ PROYEKSINYA } \\
\hline & & \multicolumn{2}{|c|}{ ARITMATIKA } & \multicolumn{2}{|c|}{ GEOMETRIK } \\
\hline & & $r$ & $\mathbf{P}$ & $r$ & $\mathbf{P}$ \\
\hline 2016 & 208.19 & \multirow{5}{*}{$30.15 \%$} & 208.19 & \multirow{5}{*}{$21.87 \%$} & 208.19 \\
\hline 2017 & 324.66 & & 270.96 & & 253.73 \\
\hline 2018 & 358.49 & & 333.74 & & 309.22 \\
\hline 2019 & 398.30 & & 396.51 & & 376.85 \\
\hline 2020 & 459.28 & & 459.28 & & 459.28 \\
\hline \multicolumn{3}{|c|}{ Standar Deviasi } & 99.25 & & 99.54 \\
\hline \multicolumn{3}{|c|}{ Koefisien Korelasi } & 0.9719 & & 0.9495 \\
\hline 2025 & & & 1151.68 & & 1234.81 \\
\hline
\end{tabular}

Syarat penentuan metode terbaik adalah:

- Standar Deviasi yang paling kecil

- Koefisien korelasi yang mendekati 1 
Metode yang memenuhi syarat diatas adalah metode Aritmatika, jadi proyeksi PDRB bidang Jasa Kesehatan dan Kegiatan Sosial untuk Kabupaten Luwu 5 tahun kedepan adalah 1151.68 miliar rupiah.

- Jasa Lainnya

\begin{tabular}{|c|c|c|c|c|c|}
\hline \multirow{3}{*}{ TAHUN } & \multirow{3}{*}{ Jasa Lainnya } & \multicolumn{4}{|c|}{ PROYEKSINYA } \\
\hline & & \multicolumn{2}{|c|}{ ARITMATIKA } & \multicolumn{2}{|c|}{ GEOMETRIK } \\
\hline & & $r$ & $\mathbf{P}$ & $r$ & $\mathbf{P}$ \\
\hline 2016 & 34.38 & \multirow{5}{*}{$10.60 \%$} & 34.38 & \multirow{5}{*}{$9.24 \%$} & 34.38 \\
\hline 2017 & 38.25 & & 38.03 & & 37.56 \\
\hline 2018 & 45.20 & & 41.67 & & 41.03 \\
\hline 2019 & 50.38 & & 45.32 & & 44.82 \\
\hline 2020 & 48.96 & & 48.96 & & 48.96 \\
\hline \multicolumn{3}{|c|}{ Standar Deviasi } & 5.76 & & 5.77 \\
\hline \multicolumn{3}{|c|}{ Koefisien Korelasi } & 0.9454 & & 0.9313 \\
\hline 2025 & & & 74.91 & & 76.17 \\
\hline
\end{tabular}

Syarat penentuan metode terbaik adalah:

- Standar Deviasi yang paling kecil

- Koefisien korelasi yang mendekati 1

Metode yang memenuhi syarat diatas adalah metode Aritmatika, jadi proyeksi PDRB bidang Jasa lainnya untuk Kabupaten Luwu 5 tahun kedepan adalah 74.91 miliar rupiah. 


\begin{tabular}{|c|c|c|c|c|c|}
\hline \multirow{3}{*}{ TAHUN } & \multirow{3}{*}{$\begin{array}{l}\text { Produk Domestik } \\
\text { Regional Bruto }\end{array}$} & \multicolumn{4}{|c|}{ PROYEKSINYA } \\
\hline & & \multicolumn{2}{|c|}{ ARITMATIKA } & \multicolumn{2}{|c|}{ GEOMETRIK } \\
\hline & & $\mathbf{r}$ & $\mathbf{P}$ & $r$ & $\mathbf{P}$ \\
\hline 2016 & 11851.86 & \multirow{5}{*}{$8.82 \%$} & 11851.86 & \multirow{5}{*}{$7.84 \%$} & 11851.86 \\
\hline 2017 & 13026.83 & & 12896.66 & & 12781.46 \\
\hline 2018 & 14441.94 & & 13941.47 & & 13783.98 \\
\hline 2019 & 15657.67 & & 14986.27 & & 14865.12 \\
\hline 2020 & 16031.07 & & 16031.07 & & 16031.07 \\
\hline \multicolumn{3}{|c|}{ Standar Deviasi } & 1651.98 & & $1,652.68$ \\
\hline \multicolumn{3}{|c|}{ Koefisien Korelasi } & 0.9858 & & 0.9786 \\
\hline 2025 & & & 23097.18 & & 23384.74 \\
\hline
\end{tabular}

Syarat penentuan metode terbaik adalah:

- Standar Deviasi yang paling kecil

- Koefisien korelasi yang mendekati 1

Metode yang memenuhi syarat diatas adalah metode Aritmatika, jadi proyeksi Produk Domestik Regional Bruto untuk Kabupaten Luwu 5 tahun kedepan adalah 23097.18 miliar rupiah. 


\section{DAFTAR PUSTAKA}

Fisu, A. A., \& Didiharyono, D. (2020, April). Economic \& Financial Feasibility Analysis of Tarakan Fishery Industrial Estate Masterplan. In IOP Conference Series: Earth and Environmental Science (Vol. 469, No. 1, p. 012002). IOP Publishing.

Fisu, A. A., \& Marzaman, L. U. (2018). Pemetaan Partisipatif Kampung Pesisir Kelurahan Tallo Kota Makassar. To Maega: Jurnal Pengabdian Masyarakat, 1(1), 22-28.

(BPS - Statistics Indonesia)Kabupaten Luwu."Produk Domestik Regional Bruto (Lapangan Usaha)" (BPS - Statistics Indonesia)Kabupaten Luwu.

Nyompa, S., Dewi, N. A. S., \& Sideng, U. (2020). Dampak Keberadaan Tambang Pasir Terhadap Kondisi Sosial Ekonomi Masyarakat di Desa Cimpu Utara Kecamatan Suli Kabupaten Luwu. LaGeografia, 18(2), 137-149.

Haqq, A. N. (2017). Tinjauan Pengembangan Kawasan Pemukiman di Belopa Ibukota Kabupaten Luwu (Doctoral dissertation, Universitas Islam Negeri Alauddin Makassar).

Dama, H. Y. (2016). Pengaruh Produk Domestik Regional Bruto (PDRB) Terhadap Tingkat Kemiskinan di Kota Manado (Tahun 2005-2014). Jurnal Berkala IImiah Efisiensi, 16(3).

Badan Pusat Statistik Kabupaten Luwu. 2021. “Kabupaten Luwu Dalam angka 2021” Badan Pusat Statistik Kabupaten Luwu.

Badan Pusat Statistik(BPS - Statistics Indonesia)" Produk Domestik Regional Bruto (Pengeluaran)" Badan Pusat Statistik(BPS - Statistics Indonesia). 2021.

Darda, T., Patra, I. K., \& Mustafa, S. W. (2021). ANALISIS KETIMPANGAN PEMBANGUNAN DI KABUPATEN LUWU TAHUN 2011-2019. Jurnal IImiah Ekonomi dan Bisnis, 18(2), 176-182.

Nappu, B., Taufik, M., \& Topik, M. (2016). Sistem Usaha Tani Kakao Berbasis Bioindustri Pada Sentra Pengembangan di Kabupaten Luwu Sulawesi Selatan. 